\title{
CORRESPONDENCE
}

\section{Coal as Britain's security}

\author{
From the Chairman of the National Coal Board
}

SIR - Your uncustomarily superficial and misleading article (21 January 1982, p.177) accuses the National Coal Board and the Government of being "in collusion to make water run uphill".

What, in fact, the NCB, the trade unions and the Government are jointly involved in is to ensure the security of future energy supplies for Britain by developing new and

reconstructed collieries so that sufficient coal continues to flow to power stations, industry and homes and the country can continue, progressively, to diminish its dependence on oil.

Throughout the 1960 s the coal industry was starved of capital when the policy of successive governments was to rely on plentiful supplies of cheap Middle East oil. Since the Middle East crisis of 1973-74 which changed that shortsighted strategy, investment in new and replacement mining capacity - essential to ensure continuity of production in an extractive industry like coalmining - has totalled $£ 3$ billion and continues at the level of more than $£ 700$ million per year. Because it takes about 10 years to develop a major new colliery, there is an obvious short-term financial burden of meeting heavy interest charges before coal production begins. That is one of the main problems the coal industry faces today and it is the legacy of earlier years of strategic neglect.

Your article scarcely recognizes the industry's considerable achievements. The coal we supply today is about two-thirds the price of oil and meets nearly 40 per cent of Britain's entire energy needs. Productivity in 1981-82 has so far risen by 5 per cent at the coal face and more than 3 per cent overall. After a previous period of decline, output at long-life collieries has increased by more than 7 million tonnes in the past three years. Exports have doubled for the third year running, and will reach about 10 million tonnes of coal and coke, which - with the addition of machinery exports by the manufacturing companies and mining consultancy services - will earn for Britain over $£ 500$ million in foreign currency.

Particularly in these times of continuing recession the British economy benefits from major purchases of goods and services from the National Coal Board - totalling $£ 983$ million in 1980-81 and having an overseas content of only $£ 26$ million ( 2.6 per cent).

It is astonishing to find you now repeating the same question that was asked in the $1960 \mathrm{~s}$ of whether Britain needs a coal industry. An independent answer was recently given by the report of the Commission on Energy and the Environment which supported the coal indsutry's continuing large-scale investment. The Commission, whose chairman was Lord Flowers, stated that: "In both the energy and the environmental interest, we consider that greater stability of long-term planning is the essential pre-condition of successful modernization of the industry".

The Commission's conclusions on coal imports will also interest your readers: "We believe that most western governments will continue to find it sensible to favour indigenous coal supplies, and to be unwilling to jeopardize sensible long-run developments by allowing customers to play the market by allowing short bursts of low-cost imports of coal during temporary recessions. Most importantly, we recognize the social unacceptability of repeating in the last decades of the century the sequence of creation and then destruction of mining communities."

DEREK EzRA

National Coal Board, London $S W 1, U K$

\section{Commercial risk}

SIR - There is surprisingly little discussion about the ways in which the practice of the biological sciences is changing as a result of the massive commercial investment in biotechnology. While some, like myself, may find the growing commercialization of bioscience depressing, there seems little one can do to stop its spread. But there is one aspect of the process that is an outrage, and bioscientists and the public agencies that fund them should unite to prevent its continuing.

Increasing numbers of scientists are giving their monoclonal-antibody-producing hybridoma cell lines to commercial companies and are then refusing to provide the antibodies and/or the cells to their colleagues. It can be argued that by relieving scientists of the timeconsuming task of sending materials around the world, commercial distribution aids rather than hinders the distribution process. But in many cases the cell lines themselves are not made available and the cost of the antibodies is prohibitive if they are needed in large amounts.

The withholding of cells and antibodies for financial gain (or even worse, for selfish scientific advantage) is especially outrageous when these have been developed using public funds. Since it is the granting agencies that must ultimately pay for reagents that would otherwise be free and must endure the slowed pace of scientific advance resulting from the restricted exchange of materials, they should be leading the fight against such anti-science practices. Instead, it has been left to a few enlightened journals, such as Cell and Immunogenetics, to take up the cause and make free availability of cell (and DNA) clones and antibodies a condition of publication. Is it not time that the granting agencies followed suit and made free availability a condition of financial support?

The American Type Culture Collection was set up to provide a free cell banking and distribution service and has recently taken over the cell bank previously located at the Salk Institute, which contains a number of monoclonal-antibody-producing hybridomas. It would be helpful if this admirable facility were extended to include the distribution of those DNA clones and antibodies that are in especially heavy demand. There could then be no legitimate excuse for scientists not making their clones and antibodies freely available to their colleagues.

Free exchange between scientists is too important to be given up without a struggle. Without it, not only is efficiency sacrificed, but much of the joy of science will be lost as well.

Zoology Department,

Martin RafF

University College London,

London, UK

\section{Spacecraft in orbit}

SIR - The suggestion put forward by David Hughes 1 that the number of objects in nearEarth orbit has recently been decreasing, thus lowering the probability of spacecraft collisions, is seriously outdated. The data he presents, which stop at the end of 1980 , show a small decrease in the number of objects in orbit from a peak in early 1978 until the end of 1980. However, during 1981 the number of objects in orbit rose rapidly, to an all-time high of 4,740 objects in October 1981 (NASA Satellite Situation Reports). From December 1980 to October 1981 the net increase of objects in orbit was 319 . Most of these new objects resulted from two events. Early in 1981,137 new objects associated with the US Landsat 3 satellite, launched in 1978, were

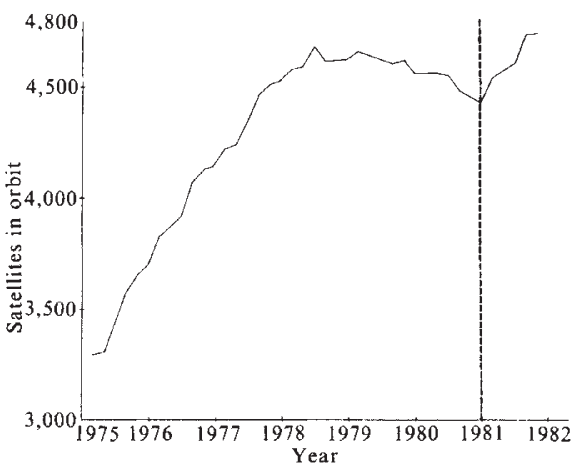

Data from NASA satellite situation reports. The previous chartl finished where the dashed line indicates.

detected. If this is another case of an exploding rocket motor, it indicates that the problem may not yet be solved. Another 118 objects associated with the USSR's Cosmos 1275 were identified shortly after its 4 June 1981 launch. If this rate of increase of objects in orbit continues, the first collision between satellites would be expected in the next 10-15 years according to calculations by Kessler and Cour-Palais ${ }^{2}$. A reversal of this trend is required to prevent a serious hazard to orbiting satellites in the twenty-first century.

Washington University,

George J. FlynN

St Louis,

Missouri, USA

1. Hughes, D.W. Nature 295, 100 (1982).

2. Kessler, D.J. \& Cour-Palais, B.G. J. geophys. Res. 86 2637 (1978) 